\title{
Effect of Duration of Exposure to Anesthetic agents on Liver and Kidney Functions of Anesthesiologists
}

\author{
Noha Esmael Ebrahem ${ }^{1 *}$ Eman S. Shaltout ${ }^{1}$.
}

\begin{tabular}{|c|c|}
\hline & ABSTRACT \\
\hline $\begin{array}{l}\text { KEYWORDS } \\
\text { Anesthesiologist, } \\
\text { Anesthetic gases, } \\
\text { Liver function, } \\
\text { Kidney function. }\end{array}$ & $\begin{array}{l}\text { Exposure to anesthetic gases, particularly halogenated agents, can result in } \\
\text { health hazards on operating room personnel especially anesthesiologists. This study } \\
\text { aimed to evaluate the effect of duration of exposure to anesthetic gases on the liver } \\
\text { and kidney functions of anesthesiologists. } 80 \text { blood donors participated in the study; } \\
20 \text { healthy unexposed office workers (control group), and } 60 \text { exposed } \\
\text { anesthesiologists. Exposed subjects were divided into } 3 \text { groups; group I was exposed } \\
\text { to anesthetic gases for < } 10 \text { years, group II was exposed to anesthetic gases for } 10-20 \\
\text { years, while group II has }>20 \text { years of exposure. During work, all exposed subjects } \\
\text { were exposed to a complex mixture of anesthetic agents. The most commonly used } \\
\text { anesthetics were halothane and Isoflurane. Venous blood samples were drawn from } \\
\text { each subject into tubes without the addition of an anticoagulant. Aspartate } \\
\text { aminotransferase (AST), alanine aminotransferase (ALT), alkaline phosphatase } \\
\text { (ALP), total bilirubin (TB), Albumin, Total protein, Blood Urea Nitrogen (BUN), } \\
\text { creatinine (Cr) were analyzed. ALT and AST showed a significant difference } \\
\text { between groups while their values were within normal ranges. Concerning the kidney } \\
\text { function tests among anesthetists exposed to anesthetic agents, BUN and creatinine } \\
\text { levels were within normal range without significant difference between groups. In } \\
\text { conclusion, the current study showed that anesthesiologists were more at risk to } \\
\text { develop health hazards related to exposure to waste anesthetic gases. }\end{array}$ \\
\hline
\end{tabular}

\section{Introduction}

Contamination of operating rooms with anesthetic gases is unavoidable due to the probability of leakage from anesthesia systems and the release of waste anesthetic gases (WAGs) through patients' expiration. Halogenated anesthetics, including halothane, isoflurane, desflurane, sevoflurane, and nitrous oxide (N2O) are the main constituents of WAGs (Odette, 2018).

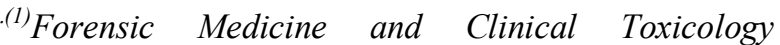
Department, Faculty of Medicine, Assiut University, Egypt.
}

Chronic exposure to WAGs can lead to health hazards and more than 200,000 health professionals are at risk of occupational diseases because of WAGs According to records of the American Occupational Safety and Health Administration (OSHA). Because it is a public health matter, knowledge of these risks and adoption of regulations that reduce ambient air pollution in the operating room to minimum levels are critical issues (Lucio et al., 2018).

Long-term exposure to anesthetic gases, particularly halogenated agents, can result in neurotoxicity, genotoxicity, 
congenital malformations, as well as liver and kidney damage (Jafari et al., 2018).

The results of epidemiological studies as regard exposure to anesthetic agents are still controversial. Some investigators believe there is no causal relationship between exposure to trace concentrations of inhalational anesthetic gases and the probable development of health hazards (McGregor, 2000). However, some other researchers have reported that long-term occupational exposure to low levels of these gases has adverse effects on the health of operating room personnel (Casale et al., 2014).

The study aimed to evaluate the effect of duration of exposure to anesthetic gases on the liver and kidney functions of anesthesiologists.

\section{Patients and Methods:}

The current study is a cross- sectional study that was conducted after obtaining ethical approval from the ethical committee, Faulty of Medicine, Assuit University (code no. 17300579). All participants received detailed information concerning the aims of this research work, and informed consent was obtained from each of them before the beginning of the study.

A total of 80 blood donors participated in the study; 20 healthy unexposed office workers (control group), and 60 exposed personnel.

The control group included 20 individuals (10 males and 10 females) aged from 30 to 65 years. They were selected from the same hospital population, but with no history of occupational exposure to anesthetic agents.
The exposed personnel were anesthetists (35 males, 25 females) aged from 30 to 65 years.

All subjects were non-smoker without a history of chronic illness particularly liver and kidney diseases and did not take any hepatotoxic or nephrotoxic drugs and also, not exposed to any kind of radiation or chemotherapy.

Exposed subjects were divided into 3 groups; group I: persons that were exposed to anesthetic gases for $<10$ years, group II: persons were exposed to anesthetic gases for 10-20 years, while group III: persons were exposed to anesthetic gases for $>20$ years.

During work, all exposed subjects were exposed to a complex mixture of anesthetic agents. The most commonly used anesthetics were halothane and Isoflurane.

\section{Blood sample collection:}

Venous blood samples (approximately $5 \mathrm{ml}$ ) were drawn from each subject into plain tubes. Samples were coded, transmitted on icebox to the laboratory, to be processed.

Aspartate aminotransferase (AST), alanine aminotransferase (ALT), total bilirubin (TB), Albumin, Total protein, Blood Urea Nitrogen $(\mathrm{BUN})$, creatinine $(\mathrm{Cr})$ were analyzed.

The reference values of them are:

AST (Aspartate aminotransferase): 10$40 \mathrm{U} / \mathrm{L}$

ALT (Alanine aminotransferase): 10-55U/L

ALP (Alkaline phosphatase):45-115U/L

Bilirubin Total: $0.3-1.2 \mathrm{mg} / \mathrm{dl}$

Total protein: $6.2-8(\mathrm{~g} / \mathrm{dl})$

Albumin: $35-60 \mathrm{~g} / \mathrm{dl}$

Urea: $23-43 \mathrm{mg} / \mathrm{dl}$

Creatinine: $0.8-1.4 \mathrm{mg} / \mathrm{dl}$ 


\section{Statistical analysis}

Data were analyzed using an advanced statistical package for social sciences (SPSS version 20.0) (SPSS, Inc., Chicago, IL). The results were expressed as frequency and percent in qualitative data and mean \pm SD for quantitative data. Parametric data were analyzed using ANOVA test and T- test, while non-parametric data were analyzed using the Manwitny test.

\section{Results}

Regarding the demographic data and patient characteristics, there was a significant difference in age between groups with a pvalue $<0.001$. However, the sex and BMI did not show significant changes between groups (Table 1).

Table (1): Demographic criteria of all studied groups.

\begin{tabular}{|l|c|c|c|c|c|}
\hline Variables & $\begin{array}{c}\text { Group I } \\
(\mathbf{n = 2 0})\end{array}$ & $\begin{array}{c}\text { Group II } \\
(\mathbf{n = 2 0})\end{array}$ & $\begin{array}{c}\text { Group III } \\
(\mathbf{n = 2 0})\end{array}$ & $\begin{array}{c}\text { Control } \\
(\mathbf{n = 2 0})\end{array}$ & p- value \\
\hline Age & $34.25 \pm 2.9$ & $44.60 \pm 4.3$ & $57.05 \pm 4.3$ & $46.05 \pm 11.6$ & $<0.001^{*}$ \\
\hline Sex (male/female, $\mathrm{n})$ & $12 / 8$ & $10 / 10$ & $13 / 7$ & $10 / 10$ & 0.800 \\
\hline BMI & $25.25 \pm 5.5$ & $24.85 \pm 5.2$ & $25.64 \pm 5.4$ & $24.65 \pm 5.3$ & 0.946 \\
\hline
\end{tabular}

BMI: body mass index, *, p- value $<0.05 \%$ using ANOVA test, $n$ : number

As regards the liver function tests in all studied groups, ALT and AST showed a significant difference between groups with Pvalue $(0.012$ and 0.010$)$ respectively. While there was no significant difference in the ALT and AST values between groups. Moreover, there was a significant difference between groups II and IV for ALT, AST. Also, there was significant difference between groups III and IV for ALT, AST. Furthermore, significant difference was found between groups I and III for ALT, AST (Table 2).

Table (2): Liver function tests in all studied groups.

\begin{tabular}{|l|c|c|c|c|c|}
\hline \multicolumn{1}{|c|}{ Variable } & $\begin{array}{c}\text { Group I } \\
(\mathbf{n = 2 0})\end{array}$ & $\begin{array}{c}\text { Group II } \\
(\mathbf{n = 2 0})\end{array}$ & $\begin{array}{c}\text { Group III } \\
(\mathbf{n = 2 0})\end{array}$ & $\begin{array}{c}\text { Control group } \\
(\mathbf{n = 2 0})\end{array}$ & p- value \\
\hline ALT(U/L) & $30.80 \pm 9.4$ & $35.05 \pm 9.6^{\mathrm{b}}$ & $40.32 \pm 15.8^{\mathrm{c}, \mathrm{e}}$ & $28.75 \pm 9.9$ & $0.012^{*}$ \\
\hline AST(U/L) & $29.42 \pm 6.9$ & $32.50 \pm 8.4^{\mathrm{b}}$ & $37.55 \pm 14.2^{\mathrm{c}, \mathrm{e}}$ & $27.55 \pm 7.5$ & $0.010^{*}$ \\
\hline ALP(U/L) & $66.00 \pm 20.66$ & $71.30 \pm 21.6$ & $69.60 \pm 20.6$ & $66.35 \pm 21.22$ & 0.820 \\
\hline Bilirubin (mg/dl) & $0.7 \pm 0.4$ & $0.75 \pm 0.44$ & $0.73 \pm 0.42$ & $0.68 \pm 0.43$ & 0.96 \\
\hline Albumin (g/dl) & $51.60 \pm 8.02$ & $50.65 \pm 9.6$ & $49.15 \pm 6.6$ & $51.20 \pm 8.5$ & 0.79 \\
\hline Total protein (g/dl) & $7.2 \pm 0.7$ & $7.2 \pm 0.7$ & $7.07 \pm 0.7$ & $6.9 \pm 0.7$ & 0.73 \\
\hline
\end{tabular}

*: p-value $<0.05 \%$ using ANOVA test, n: number, ALT: Alanine aminotransferase AST: Aspartate aminotransferase, ALP: Alkaline phosphatase, ${ }^{\text {b }}$ : P-value $<0.05 \%$ between group II, IV using paired t-test: P-value $<0.05 \%$ between group III, IV using paired t-test, ${ }^{\mathrm{e}}$ : p-value $<0.05 \%$ between group I, III using paired t-test, n: number. 
Concerning the kidney function tests among anesthetists exposed to anesthetic agents, BUN and creatinine levels were within normal range without significant difference between groups (Table 3).

Table (3): Kidney function tests in all studied groups.

\begin{tabular}{|l|c|c|c|c|c|}
\hline Variable & $\begin{array}{c}\text { Group I } \\
(\mathbf{n = 2 0})\end{array}$ & $\begin{array}{c}\text { Group II } \\
(\mathbf{n = 2 0})\end{array}$ & $\begin{array}{c}\text { Group III } \\
(\mathbf{n = 2 0})\end{array}$ & $\begin{array}{c}\text { Control group } \\
(\mathbf{n = 2 0})\end{array}$ & $\begin{array}{c}\text { p- } \\
\text { value }\end{array}$ \\
\hline Urea $(\mathrm{mg} / \mathrm{dl})$ & $27.86 \pm 8.67$ & $25.97 \pm 8.61$ & $30 \pm 9.34$ & $26 \pm 8.91$ & 0.7 \\
\hline Creatinine $(\mathrm{mg} / \mathrm{dl})$ & $0.82 \pm 0.24$ & $0.78 \pm 0.31$ & $0.81 \pm 0.31$ & $0.85 \pm 0.18$ & 0.8 \\
\hline
\end{tabular}

n: number

\section{Discussion}

Exposure to anesthetic agents in the operating room, recovery room, may entail a health risk for the personnel exposed. Although health care workers are exposed to much lower anesthetic concentrations than the patients, this exposure often extends over many years (Al-Ashour et al., 2014).

The possible adverse effects of longterm exposure to trace levels of anesthetic gases in operating room personnel have been a matter of concern (Jafari et al., 2018).

This study is a cross- sectional study done to evaluate the effect of duration of exposure to anesthetic gases on the liver and kidney functions of anesthesiologists.

All exposed subjects were exposed to a complex mixture of anesthetic agents. The most commonly used anesthetics were halothane and Isoflurane.

Our study revealed a statistically significant increase in the mean value of ALT and AST among exposed groups compared to the control group. Moreover, the mean value of ALT and AST increases with the increase in the period of exposure with higher values among the group who exposed to anesthetic agents for more than 20 years. However, the mean of all measured parameters was within normal ranges. This was in agreement with
Casale et al. (2014) who investigated the effect of anesthetic gases on 119 operating room personnel in Italy, as they found that AST and ALT, were significantly higher among exposed than the control group. Also, the current work was similar to that of Siha et al. (2019), in their study on liver enzymes changes induced by anesthetic gases among the operation room personnel, when a total of 46 persons, who worked in the operating room more than 3 hours a day, 3 days a week, were chosen and compared with a control group. They found that all liver enzymes were significantly higher among the exposed group.

These controversial findings suggest that other factors, including duration and severity of exposure, the type of anesthetic gases, age, gender, co-exposure to other chemicals may affect the hepatotoxicity of these agents.

Overall, the side effects of anesthetic agents, including halothane, nitrous oxide, isoflurane, and sevoflurane are dependent on the magnitude and frequency of exposure (Jafari et al., 2018). Also, it is known that chronic exposure is mainly a risk factor for hepatotoxicity of halogenated anesthetic gases (Bauer and Raupach, 2019).

Several mechanisms are responsible for hepatic injury following exposure to 
anesthetic gases. Fassoulaki et al. (1984) reported that exposure to anesthetic agents is expected to be associated with hepatotoxicity due to the decrease in liver blood flow. Halogenated agents can also cause liver damage through the disruption of cellular calcium homeostasis mechanisms (Shi et al., 2017).

It is of interest to note that the mean values of kidney tests (BUN and creatinine) were within the normal range in all groups without statistically significant change in the level of urea and creatinine, among exposed when compared to the control group. This finding is the same as what was found by Mohamed et al. (2003) where they didn't reveal any change in the level of serum creatinine or blood urea nitrogen (BUN), between exposed and control groups in their study on the effect of anesthetic gases on the operating room personnel. similarly, Trevisan et al. (2003) studied the effect of waste anesthetic agents on renal function of exposed personnel and found that renal function biomarkers were not affected by these agents. Correspondingly, Neghab et al. (2020) reported that exposure to low-flow of isoflurane and sevoflurane are not associated with significant renal effects. Likewise, Qin et al. (2019) did not find any difference in creatinine levels after exposure to sevoflurane and isoflurane anesthesia.

In contrast to what was found by Caciari et al. (2013) in their study on occupational exposure to anesthetic gases among health workers where they found a significant increase in serum creatinine in 145 exposed subjects compared to 89 non-exposed controls. This was probably due to the numerous limitations in the use of serum creatinine and BUN as sensitive and specific biomarkers for early detection of kidney injuries. Serum creatinine and BUN are two useful indicators for evaluating kidney function. First, many non-renal factors such as age, sex, race, body weight, diet, and drug consumption can influence serum creatinine levels. Second, the production rate of urea is not stable and depends upon the consumption of protein-rich diets and increases under certain situations such as bleeding, muscle trauma, or steroid administration (Klaassen Curtis D et al., 2013).

\section{Conclusion:}

The current study showed that anesthesiologists were at risk to develop health hazards related to exposure to waste anesthetic gases. These hazards included elevation in liver function which is related to the prolonged exposure to anesthetic gases over years.

\section{Recommendations:}

The researchers recommend that further studies should be employed to involve a large number of health staff members. Implementation of adequate scavenging of waste anesthetic gases with securing adequate functioning of air conditioning systems, periodic measurement of anesthetic gases in the operating room to ensure keeping them within the safe levels. Periodic examination of personnel working in the operating room in addition to the use of closed systems of anesthesia whenever possible and treatment of any health problems

\section{Conflict of interest}

The authors declared that there is no conflict of interest exists.

\section{Funding}

None. 


\section{Acknowledge:}

The authors would like to thank all the personnel who participated in this study.

\section{References:}

Al-Ashour; Ibrahim, A.K.; Abd-Ali, D.K.; et al. (2014) 'Effect of inhaled anesthetics gases on health staff health status in Al-Najaf City', International Journal of Technology Enhancements Emerging Engineering Research, 3(12), p. 383-388.

Bauer, I. and Raupach, A. (2019) 'The role of heme oxygenase-1 in remote ischemic and anesthetic organ conditioning', Antioxidants, 8(9), p. 403.

Caciari, T.; Capozzella, A.; Tomei, F.; et al. (2013) 'Professional exposure to anaesthetic gases in health workers: estimate of some hepatic and renal tests', La Clinica Terapeutica, 164(1), p. e5-9.

Casale, T.; Caciari, T.; Rosati, M.V.; et al. (2014) 'Anesthetic gases and occupationally exposed workers', Enviromental Toxicology, 37(1), p. 267-274.

Fassoulaki, A.; Eger, E.I.; Johnson, B.H.; et al. (1984) 'Brief periods of hypoxia can produce hepatic injury in rats', Anesthesia 63(10), p. 885-887.

Jafari, A.; Jafari, F. and Mohebbi, I. (2018) 'Effects of occupational exposure to trace levels of halogenated anesthetics on the liver, kidney, and oxidative stress parameters in operating room personnel', Toxin Reviews, p. 1-10.

Klaassen C.D.; Amdur M.O. and J.D. (2013) Casarett and Doull's
Toxicology: The Basic Science of Poisons, McGraw-Hill New York.1236, p. 1-2. 3rd edition.

Lucio, L.; Braz, M.G.; Nascimento Junior, P.D.; et al. (2018) 'Occupational hazards, DNA damage, and oxidative stress on exposure to waste anesthetic gases', Revista Brasileira de Anestesiologia, 68(1), p. 33-41.

Mcgregor, D.G. (2000) 'Occupational exposure to trace concentrations of waste anesthetic gases', Mayo Clinic Proceedings, Elsevier, 75 (3), p.273277.

Mohamed, M.; Abdellatif, M.; Sabar, A.; et al. (2003) 'Sodium fluoride ion and renal function after prolonged sevoflurane or isoflurane anaesthesia', Eng. J. Ana., 19, p. 78-83.

Neghab, M.; Amiri, F.; Soleimani, E.; et al. (2020) 'Toxic responses of the liver and kidneys following occupational exposure to anesthetic gases', EXCLI journal, 19, p. 418.

Odette, O. (2018) 'Hazards of the anesthetic delivery system and operating room fires', Veterinary Anesthetic and Monitoring Equipment, p. 115.

Qin, Y.; Ni, J.; Kang, L.; et al. (2019) 'Sevoflurane effect on cognitive function and the expression of oxidative stress response proteins in elderly patients undergoing radical surgery for lung cancer', J. Coll. Physicians Surg. Pak., 29 (1), p. 1215.

Shi, Q.; Yang, X.; Greenhaw, J.J.; et al. (2017) 'Drug-Induced liver injury in children: clinical observations, animal models, and regulatory status', Internationa Journal of Toxicology, 36(5), p. 365-379. 
Siha, M.; Farahat, S.; Rashed, L.; et al. (2019) 'Study of some health hazards among operating theater personnel due to exposure to anesthetic gases (Ii)', Egyptian Journal of Occupational Medicine, 43(3), p. 313-329.
Trevisan, A.; Venturini, M.B.; Carrieri, M.; et al. (2003) 'biological indices of kidney involvement in personnel exposed to sevoflurane in surgical areas', American Journal of Industrial Medicine 44 (5), p. 474-480. 


\title{
تأثير فتزه التعرض للمواد المخدره على وظائف الكبد والكلى لأطباء التخدير
}

\author{
نها إسماعيل إبراهيم ، ايمان صلاح شلتوت'
}

$$
\text { ' قسم الطب الثرعي وعلم السموم الإكلينيكية، كلية الطب، جامعة أسيوط }
$$

يمكن أن يؤدي التعرض لغازات التخدير، وخاصة المواد المهلجنة، إلى مخاطر صحية على موظفي

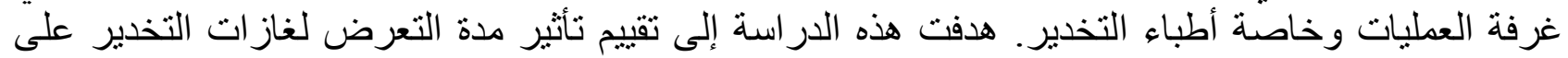

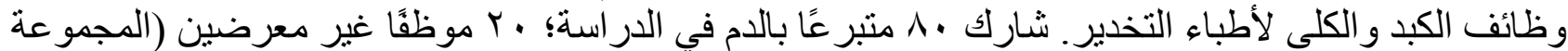

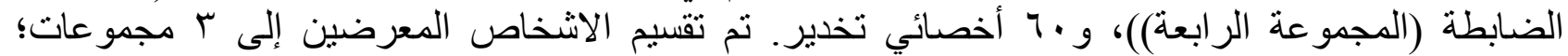

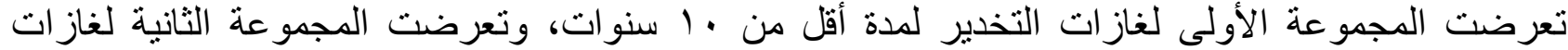

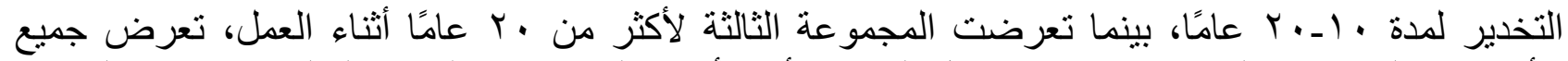

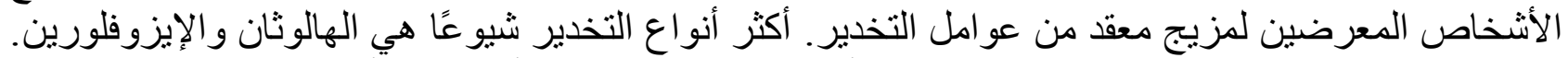

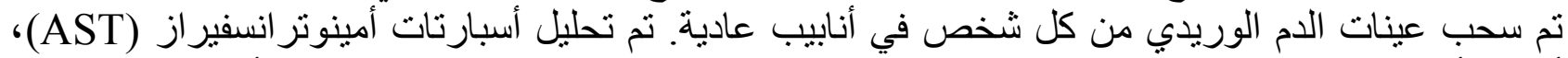

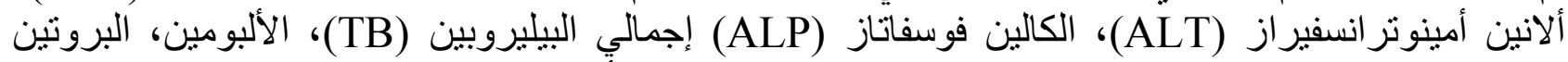

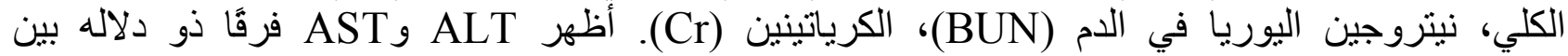

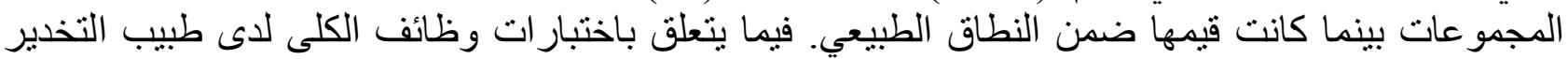
المعرض لعو امل التخدير، كانت مستويات BUN و الكرياتينين ضمن المعدل الطبيعي دون فرق ذو دلاله بله بين

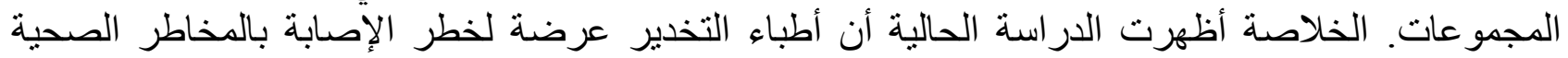
المتعلقة بالتعرض لنفايات غاز ات التخدير. 